\title{
Insight
}

\section{Separating Adaptive Maintenance (Resilience) and Transformative Capacity of Social-Ecological Systems}

\author{
Samuel Wilson ${ }^{1,2}$, Leonie J. Pearson ${ }^{1,3}$, Yoshihisa Kashima ${ }^{1,4}$, Dean Lusher ${ }^{5}$ and Craig Pearson $^{1}$
}

\begin{abstract}
Many rural communities are vulnerable social-ecological systems (SES) that must do more than become resilient to future environmental and social shocks: they must transform to achieve sustainability. We aimed first to conceptually explore the proposition that SES characteristics (identity, feedbacks, structure, and functions) necessary for transformation may be distinct from those necessary for adaptive maintenance or resilience, and second, to propose metrics that may be used to assess these two types of system changes. We did this by interrogating literature and by investigating two rural towns in Australia using a combination of quantitative methods and focus groups to interrogate community social networks, capitals (human, natural, built, and social) and future scenarios. Results indicated that (1) it is practicable to carry out a holistic assessment of SES characteristics (identity, feedbacks, structure, and functions), and (2) purposeful, positive transformation is supported by vision, identification with place, unhappiness (with the status quo), high personal contribution to social capital, open social networks, and latent capital(s). We conclude that rural communities possess capacities for adaptive maintenance (resilience) and for system-wide transformation, and that the metrics used to assess each are sometimes discrete, sometimes common.
\end{abstract}

Key Words: Australia; feedbacks; functions; identity; structure

\section{INTRODUCTION}

The sustainability literature is replete with references to socialecological system (SES) resilience and transformation. Although the idea of change is germane to both concepts, the nature and consequence of change in each is distinct. There is a growing call (O'Brien 2011, Pelling 2011, Pelling and Manuel-Navarrete 2011) for more studies to investigate the two types of system changes to understand their distinctions and similarities, and how to deliberately transform systems and society. The purpose of this paper was to contribute to our understanding of the distinction between SES resilience and transformation, grounded in empirical research into two rural Australian communities.

Resilience is the ability of an SES to absorb disturbance and reorganize to retain "essentially the same function, structure, identity, and feedbacks" (Walker et al. 2004). Concern for SES resilience (originally from the discipline of ecology, e.g., Holling 1973) and adaptive capacity (from a social-ecological perspective, e.g., Berkes et al. 2003) has focused on efforts to enhance resilience and avoid system "failure", collapse, regime shifts, or transformation (e.g., Vogel et al. 2007, Biggs et al. 2009).

By contrast, transformation is accorded a diversity of meanings (Nelson et al. 2007, O’Brien 2011, and Pelling 2011 provide recent reviews). To some, transformation is "deep social change" within a resilient system (Chapin et al. 2009) or change to the "scale" of a resilient SES. Walker et al. (2006) define transformation as changing the "state of the system", reflected in changes to such system characteristics as goals, scale, and cross-system connections in space and time (i.e., panarchy). Abel et al. (2006) and Schlüter and HerrfahrdtPähle (2011) propose a typology that distinguishes between adaptive maintenance (i.e., resilience) where changes do not alter the prevailing system logic or functions-and transformation, which involves marked changes to system logic and function. We adopt a conception of transformation that is consistent with Abel et al. and Schlüter and HerrfahrdtPähle; namely, that SES transformation refers to the process of deep change of identity (goal), feedback processes, structure, and functions.

Transformation, thus defined, may be in response to unexpected or deliberate processes or events, and has negative or positive outcomes. Critically, it is implied that there is a role for SES management to either purposefully create deliberate transformation to a "positive" sustainable system (Clark and Dickson 2003, Parris and Kates 2003, Bettencourt et al. 2007) or to avoid tipping points to negative outcomes (Carpenter and Brock 2006, Carpenter et al. 2008, Guttal and Jayaprakash 2008).

Consistent with Pearson and Pearson (2012), we propose that system changes may be grouped into (i) resilient, (i.e., adaptive maintenance) or (ii) transformative. In this exploratory study, we examine the hypothesis that system characteristics necessary for transformation may be separate from, and not dependent on, the adaptive maintenance or resilience of an SES. Further, we propose metrics for some of these characteristics to assess (or predict) if an SES system will maintain itself and/or initiate system-wide transformations.

\footnotetext{
${ }^{1}$ Melbourne Sustainable Society Institute, The University of Melbourne, Australia, ${ }^{2}$ Present address: School of Psychology and Psychiatry, Monash University, Australia, ${ }^{3}$ Land and Environment, The University of Melbourne, Australia, ${ }^{4}$ Psychological Sciences, The University of Melbourne, Australia, ${ }^{5}$ Swinburne Institute of Social Research, Swinburne University of Technology, 3122 Australia
} 
We do this by interrogating the Resilience literature to identify the possible SES characteristics of transformation from the perspective of identity, feedbacks, structure, and functions. We then provide empirical estimates of these characteristics for two communities in rural Australia. By describing the characteristics needed for resilience compared with transformation, and how a community may have relatively high potential to transform without being currently resilient, we encourage a shift in thinking towards research that deliberately designs scenarios of change for enhanced sustainability.

\section{Considering each of the four SES characteristics:}

Identity: Social-ecological systems are inherently dynamic, complex, and characterized by multiple "identities". As such, identity must be defined normatively (Meadows 2008). Walker et al. (2004) use two questions: "of what?" and "to what?" to clarify SES identity with respect to specified resilience. These questions clarify the system boundary (e.g., in terms of spatial, temporal, place, or practice), and the goal, direction, or focus of the system (e.g., Scheffer et al. 2002, Pelling et al. 2008). These fundamentally physical system elements can be supplemented with a further question of "for whom?" to highlight such social concerns as power, equity, and institutions (Pelling and Manuel-Navarrete 2011).

Feedbacks: the processes of cause and effect that flow through and instantiate the system. Feedbacks describe the interactions between, and responses of, people, institutions, and the environment (Kinzig et al. 2006). "Openness" refers to how well connected a system is to systems at different scales within the nested SES hierarchy (Levin 1999). Empirical work has investigated SES feedbacks in social networks (Janssen et al. 2006) and within environmental habitats (McClanahan et al. 2002). Our study investigated feedbacks through informal social networks or shadow networks/spaces (Olsson et al. 2006, Pelling et al. 2008), examining connections within and between networks (i.e., panarchy, as discussed by Gunderson and Holling 2002). It is proposed that dense networks (high connectivity within the network) with low reachability outside of the network are locally based and are well placed to enhance adaptive maintenance (Walker and Lawson 2006). By contrast, SES that have more open feedbacks - that is, those connected to external networks, such as central government structures networks in different spatial areas, or international financial systems, have longer feedbacks and therefore have an increased chance of crossing thresholds or transforming (for example, Tompkins and Adger 2004, Anderies et al. 2006).

Structure: the pattern of relationships between the elements or parts of a system. This study investigated social network modularity and access to the underlying available capitals (natural, built, human, and social). Modularity is a core attribute of SES structure that describes the extent of linkages between high-ranking nodes in a network (Janssen et al. 2006). For example, an SES with low modularity would have key leaders with high coordination able to reinforce adaptive maintenance of the system because they have connections/ influence throughout the whole network. The second structural component is availability and access to latent or underused capitals (natural, built, human, and social). Walker et al. (2006) propose that latent capitals are necessary to be utilized for transformational change in the SES. The rationale is that if resources are being used as efficiently as possible, then there is little capacity for transformation unless a crisis occurs and capitals become available for new uses and opportunities.

Functions: the emergent outcomes (goods, services, and options) from the processes of the SES (adapted from de Groot 1992). For example, if an SES is functioning "well", we would expect happiness with status quo, high personal satisfaction, and close connectivity between personal identity and SES identity; these attributes have already been identified as necessary for SES undergoing adaptive maintenance (Gunderson and Holling 2002, Berkes et al. 2003). Alternatively, innovation and leadership have been identified as emergent properties to "potentially" improve functioning of SES that are unhappy with current goals and are necessary for deliberative transformation (e.g., Walker et al. 2006, Tschakert and Dietrich 2010).

\section{METHODS}

Two communities were studied, which we refer to as "Smith" and "Jones" (collaboration from town councils and community leaders was provided under conditions of anonymity). We chose these communities specifically because they are exemplars of rural communities in Australia: small scale, isolated, and facing the prospect of community decline in the face of socioeconomic and environmental challenges. Both communities face inevitable reductions or outright termination of water allocations from the Murray-Darling Basin, increasing climate variability, and demographic change. There are also marked differences between the two communities. Anecdotally, Smith is perceived as a stable community with a strong cultural heritage and highly dependable residential workforce, whereas Jones is regarded as culturally heterogeneous, reliant on itinerate labor, disadvantaged, and less committed to community well-being.

Smith and Jones are examples of rural communities that developed during the "age of New World expansion" from about 1600 to the 1990s in the United States, Canada, Australia, New Zealand, Argentina, Brazil, and South Africa (Pearson and Nasby 2008), and which now face "postproductivist transition" (Wilson 2001), or as Holmes (2006) puts it, a re-ordering of production, consumption, and protection. Both communities face uncertain futures, diminishing natural resources, and pressure from expected climate change, including increased drought, decreased water 
availability, and more intense and frequent floods, as well as diminishing terms of trade and an aging population. Their needs for transition to new futures must be understood within the global context of declining rural populations and services, increased awareness of rural impacts of climate change (e.g., Hafi et al. 2009, Nelson et al. 2010), and reduced political power (through the amalgamation of local governments, an increasing urban population, and a shift to remotely generated planning, e.g., Rounsevell et al. 2010). These challenges have caused governments to prioritize rural communities for assessment of, assistance with, and policies for, resilience (for example, Maguire and Cartwright 2008, Nelson et al. 2008).

We employed three analytical techniques in our study: (a) publicly available data to assess capitals and trends, and to contextually frame the issues, (b) focus groups to obtain perceptions of future scenario change, the extent that the community capitals were underemployed or "latent", and preparedness to change, and (c) questionnaires to estimate social capital, networks, and attitudes. These three techniques were chosen to generate complementary information in the most cost-effective way (e.g., using public statistics rather than collecting primary data through audit of capital stocks, and to provide some degree of informal triangulation on issues). We recognized that each technique had inherent limitations and possible biases-e.g., government employees readily admitted public statistics underestimated itinerate populations, focus groups are open to bias according to membership and process (although ours were each managed by the same two experienced facilitators), and the questionnaires were expensive and biased in that we were not able to get an even sampling across ethnic groups due to differences in preparedness to participate.

(a) Public data: We analyzed historical events and capitals from the Australian Bureau of Statistics (2001, 2006a) and Victoria Government (2006), records of local newspapers for 1980-2010, and land use data. From the analysis of public data and land use categories we contextualized the study of each town and selected various surrogates of existing capitals. From the narratives and scenarios of the focus groups we inferred the extent to which capitals were perceived as "sunk" or "flexible/latent", and community preparedness to commit to transformative future scenarios. We assigned a subjective, relative score to capitals, following the concept of Brown et al. (2010). The underlying reasoning behind our assignment of a score for each community was to demonstrate proof-ofconcept; actual scores, perhaps taken over several years, could be developed by researchers, by community groups, as in Brown et al. (2010), or through a combination of expert assessors and community groups.

(b) One focus group was conducted in each town to obtain perceptions of past trends in capitals and assess capacity to develop future scenarios. Each focus group lasted four hours. We collected perceptions of how community and its capitals had changed over the past 30 years, and developed scenarios for the next 30 years to 2040; each group obtained consensus on three future scenarios. Focus groups were held in September 2010 and were attended by three women and nine men in Smith (average age: 53.6 years; mean residence: 34.4 years), and by 11 women and five men in Jones (average age: 58.5 years; mean residence: 47.8 years).

(c) We administered questionnaires from which we estimated social capital and social networks, and attitudes and activities in the domains of environment, health and finances, and identification with and attachment to the community and the environment. The questionnaire involved 63 questions and used snowball sampling for administering to 105 people (Smith) and 59 people (Jones) in three waves of interviews in order to analyze social networks from approximately equal numbers of men and women, aged 18 to 83 (average 51) in Smith and aged 26 to 89 (average 57) in Jones. The first wave for each town started with the identification of half a dozen key individuals within the community who held positions of notoriety (e.g., mayor, head of Rotary, public positions). Each survey asked interviewees to nominate up to five people that they could approach to discuss issues about their township and the natural environment. In social network terms, they were strong ties, that is, people with whom the interviewee had close interpersonal relationships. Most people nominated five.

Responses were categorized into ethnic groups because both communities were culturally heterogeneous and this diversity was one reason for choosing Smith and Jones. Responses from Smith were categorized into three groups: Anglo-Celtic (89 respondents), Italian (9), and Other (7, including 5 Indigenous Australians). By contrast, Jones comprised five ethnically defined and socially discrete subcommunities of Anglo-Celtic, Italian, Pacific Island, Asian, and Indigenous origins. As in Smith, our sampling in Jones was biased to Anglo-Celtic members, and our statistical analysis grouped Anglo-Celtic (41 respondents), Italian (12), and Other (7, including 1 Indigenous Australian, 1 Asian, and 1 Tongan).

In addition to our analysis of the questionnaires, we used 12 questions to calculate an aggregated measure of social capital score that reflected trust, as adapted from Onyx and Bullen (2000). We used their six facets of social capital:

- Participation in the local community (our questions: "Do you help out as a volunteer"; " Have you ever been part of a project to organize a new service in [town name]?");

- Social agency ("If you disagree with what everyone else agreed on, would you feel free to speak out?"; "If you have a dispute with your neighbors, are you willing to seek mediation?");

- Feelings of trust and safety ("Do you feel safe walking down your street after dark?"; "Do you agree that most people can be trusted?"); 
- Neighborhood connections ("In the past six months, have you helped a neighbor with anything?"; "Have you visited a neighbor in the past week?");

- Family and friends connections ("When you go out in the local area, are you likely to run into friends and family?"; "Have you spoken to or conversed with friends or family during the week?"); and

- Tolerance of diversity ("Do you think that living among people of different cultural or ethnic backgrounds makes life in [town name] better?"; "Do you enjoy living among people of different lifestyles?").

Each item was rated from 1 (No, not at all) to 5 (Yes, definitely or Yes, frequently).

Additionally we asked a number of further questions to ascertain the individual's perception of their contribution to social capital (our questions: "I always work energetically to improve Smith/Jones and its natural environment, to the extent I can"; "I work energetically to make my life better, so that I am happy, healthy, and well") and their perception of the rest of the community's contribution to social capital ("People in this community work energetically to improve Smith/Jones and its natural environment"; "People in this community work energetically to make their lives better, so that they are happy, healthy and well"). Each statement was rated from 1 (Strongly disagree) to 5 (Strongly agree).

Questionnaires were analyzed with SPSS, structured according to ethnic groups with unequal class numbers to minimize sampling biases to describe perceptions of personal and community engagement and social networks.

\section{RESULTS}

\section{Identity}

Smith and Jones were established in 1912 and 1924, respectively. Both are irrigation communities and are part of what is colloquially known as the "food bowl" of Australia. Smith's population has been stable at 11,000, with relatively little itinerate labor for 30 years. Jones has a population between 6000 and 8000 , which rises to about 11,000 during various harvest periods (of months). Given that Aboriginal, Pacific islanders and migrant workers do not participate fully in censuses, the population of this community is not known with certainty. The Victorian Government (2006) independently estimates that the year-round demand for harvest labor is 6000. Smith and Jones are commercial centers for their local government areas (the basis of publicly available statistics) of 1167 and $831 \mathrm{~km}^{2}$, respectively.

Both communities' workforces are dominated by laborers (40\% in Smith, 55\% in Jones), with $20 \%$ of both resident populations classified as professionals, mostly teachers and managers. Each community has more than 100 civil, social, and sporting clubs, and multiple churches (Smith:8; Jones:12).
Both communities are on the border of what the Australian Housing and Urban Research Institute identified as vulnerable (i.e., between 4000 and 9999) (Baum et al. 1999). In particular, the vulnerability of small regional communities appears to be associated with adverse trends in income distribution, low levels of human capital, and difficulties in making the transition from low-skill, extractive-type industry employment, such as agriculture and mining, to the high-skill growth areas of the information services industry. An Australian Bureau of Statistics study based on 1986-1996 statistics identified Smith among a sample of 122 towns as belonging to a cluster of opportunity. Although Jones was not included, two neighboring towns were included in clusters of vulnerability (Baum et al. 1999). On an index of relative socioeconomic disadvantage, Smith was ranked 467th and Jones 167th in Australia (Australian Bureau of Statistics 2006b), indicating that Jones is significantly more disadvantaged than Smith.

The normative community identities for Smith and Jones can be described by addressing three questions (Introduction): SES of what? to what? and for whom? Both communities have similar current rural irrigation-dependent identity (of what?). "To what" has been reinforced as maintenance of the status quo (resilience) in Smith, which has undertaken a series of strategic plans that reaffirmed its dependence on irrigated agriculture, e.g., "food production and processing founded on irrigation" (Burns 1995) and as "a center for excellence for business and agriculture" (Smith Shire Council 2008). Whereas, Jones has no such affirmation, although the greater itinerate workforce in Jones was thought to confer flexibility, i.e., opportunity for transformation. And "for whom?", both communities have shown little desire to change institutional structure or power relationships (not explicitly investigated in this study), but both expressed a desire to reduce community inequality (e.g., income distribution and ethnic marginalization).

\section{Feedbacks}

To investigate the feedbacks within the two communities we interrogated their social networks by examining connections within the network and investigating how open the networks were to other networks (i.e., cross-scale connections). Fig. 1 illustrates the social networks, derived from our survey.

Jones' social network had greater density (i.e., it is more internally connected) than Smith's network, with Jones respondents nominating slightly more links (4.9) than respondents in Smith (4.6), $F=3.47, p=0.07$ (using a town by ethnicity two-way analysis of variance). Also, one segment of the Jones respondents (Italian) appeared to have a larger number of connections outside of the community network (that is, higher reach outside of the network) in as much as they nominated more people outside the community than did their counterparts in Smith. 
Table 1. Scores from three perspectives of social capital: personal, community, and computed Onyx and Bullen (2000) score, from survey.

\begin{tabular}{|c|c|c|c|c|c|c|c|}
\hline & \multirow[b]{2}{*}{ Ethnic group } & \multicolumn{3}{|c|}{ Smith } & \multicolumn{3}{|c|}{ Jones } \\
\hline & & Anglo-Celtic & Italian & Other & Anglo-Celtic & Italian & Other \\
\hline \multirow{2}{*}{$\begin{array}{l}\text { Self-contribution to social } \\
\text { capital }\end{array}$} & Score & 3.948 & 4.056 & 3.500 & 2.850 & 2.903 & 4.167 \\
\hline & Std error & 0.068 & 0.213 & 0.286 & 0.100 & 0.185 & 0.639 \\
\hline \multirow{2}{*}{$\begin{array}{l}\text { Perceived community contribution to social } \\
\text { capital }\end{array}$} & Score & 4.073 & 3.963 & 3.200 & 4.093 & 4.444 & 4.667 \\
\hline & Std error & 0.057 & 0.181 & 0.242 & 0.085 & 0.156 & 0.542 \\
\hline \multirow{2}{*}{$\begin{array}{l}\text { Onyx and Bullen generated social capital } \\
\text { score }\end{array}$} & Score & 4.287 & 4.361 & 3.650 & 4.287 & 4.362 & 3.750 \\
\hline & Std error & 0.500 & 0.156 & 0.209 & 0.073 & 0.135 & 0.468 \\
\hline
\end{tabular}

Fig. 1. Strong ties of the two communities differentiated by ethnic groups $($ white $=$ Anglo-Celtic, red $=$ Italian, blue $=$ other ethnicities). (A) Smith's strong-tie social network; (B) Jones' strong-tie social network

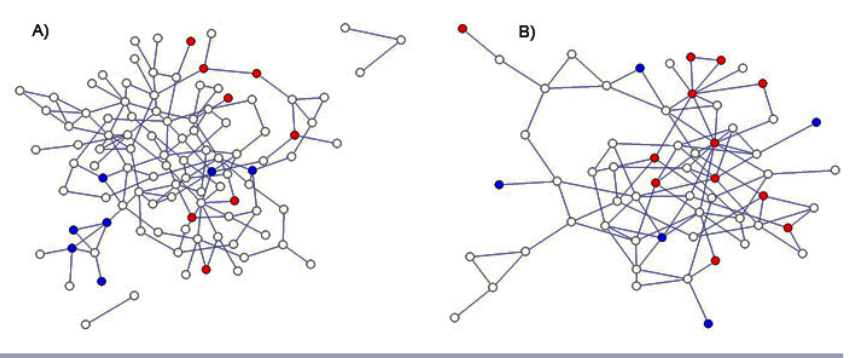

To examine the extent and to what purpose these social networks were activated, we asked how many of the people that they nominated were approached to discuss issues of town and environment, health, and finance, respectively. There was no difference for health and finance: on average, 2.7 people were approached about health and 1.2 about finance in each community. However for town and environment, Jones residents used more network connections (2.75) than did Smith residents (1.57): $F=8.95, p=0.01$.

These results show Smith's social networks had low external reach (i.e., closed feedbacks) well-suited to adaptive maintenance, whereas Jones had a greater density of social connections but with more external links. The more open feedbacks of Jones raise the possibility that this community is more amenable to transformation.

\section{Structure}

Elements of Structure include latent capitals and modularity within the community social network.

The assessment of available natural, built, and human capital stocks for both towns showed that total capital stocks were similar for the two communities, although somewhat higher for Smith (aggregate scores of 15.4 and 13.4: data available from the authors).

Natural Capital. The natural capital was assessed within a 25$\mathrm{km}$ radius of Jones and Smith. Results show Jones had less land used for irrigated perennial horticulture, crops, and livestock (5.9\% compared to $23 \%$ for Smith), while both towns had a comparable amount of land used for dry land agriculture or wildlife conservation (Jones $20.7 \%$; Smith $24.7 \%$ ). Jones had a much larger proportion of land used for low-density grazing land based on native vegetation or unoccupied land (73\%) compared to Smith's 52\%.

Built Capital. To support the agricultural sector, Jones had approximately $40 \mathrm{~km}$ of irrigation channels and $300 \mathrm{~km}$ of roads, and Smith had $450 \mathrm{~km}$ of channels and $550 \mathrm{~km}$ of roads. The channel and road data should be taken as indications of relativity of infrastructure, not absolute, because they were based on intercepts within GIS pixels, not true estimates of lengths. Supporting data are available from the authors.

Human Capital. The assessment of human capital was more challenging; however, Smith had three times as many tertiary educated people as Jones, and a more stable population. While Jones had a more dynamic population (high variability throughout the year in population numbers), which had a lower skill level, it also had lower access to health-professionals and a much higher reporting of illness and health related issues. A subjective rating of human capital was also provided, and Jones was perceived as having a lower human capital than Smith.

Social Capital. There were no differences in community social capital as estimated from the Onyx and Bullen (2000) social capital scale (Table 1). Using separate survey questions to assess personal perception of individual respondents own contribution to environmental, social, and financial strength of the community showed Smith was perceived by its inhabitants as having higher social capital, whereas personal 
contributions were seen as higher in Jones (differences significant at $p=0.05$, Table 1). That is, individuals in Jones perceived the town had less social capital, and felt they personally were working harder, or were prepared to work harder, to create it. It is noteworthy that the marginalized people ("Other" ethnicity in Table 1) in Smith felt they were personally contributing less, whereas the "Other" group in Jones felt they were contributing more. Differences among ethnic groups were statistically significant for all three data sets, including those that generated the Onyx-Bullen statistic.

These results are more nuanced than would have been obtained from a simple interpretation of the survey questionnaire without analyzing for differences among unequally sampled ethnic groups. For example, there were striking differences in the aggregated response to "The community puts a lot of energy into working together to improve the town and its environment and health and well-being", with Smith showing $83 \%$ strongly agreeing and 5\% disagreeing with this statement, while Jones had only $32 \%$ strongly agreeing and a surprising $38 \%$ disagreeing.

While these results relate to total amount of capital available in each town, an assessment of latent capital is more subjective. It was perceived by the research team that Smith had higher unused built, natural, and human capitals; however, they are redundant and sunk rather than mobile and "latent". This is because although Smith had a larger area of historically irrigated crop, and greater irrigation infrastructure, its irrigated agriculture was of low value relative to Jones', so that when (as in the past five years) there was insufficient local water for irrigation, purchasing water from another part of the MurrayDarling Basin was not economical for Smith, and there is redundant irrigation and crop processing infrastructure relative to Jones. Additionally, the human capital in Smith contained three times as many tertiary educated people as in Jones-in a sense they were "stranded" when there was a downturn in irrigated cropping-whereas in Jones there was a highly mobile workforce that was not especially dependent on maintenance of local employment.

The second aspect of SES structure was modularity, which we interrogated through social networks. Both communities had strongly identified "modules/parts" within its community network structure; these were identified along ethnic themes (Fig. 1). Smith has three (modular) ethnic groups that are clearly separated from each other and are more inward looking than Jones (Table 2), with the higher densities within modular ethnic groups than across the whole community network (block analysis undertaken using White et al. 1976). Jones showed a central, coherent, strongly connected ethnic group, "Italian", with a bridging group (the "Anglos") acting as an intermediary to the people who were classed as "Other", although they were not a coherent group (Table 2). Interestingly, within Jones there seemed to be two "centers" with a highly internally cohesive Italian community and a less internally cohesive Anglo-Celtic group that acted also as a linking structure in the community.

Table 2. This table describes the modularity of Smith and Jones' social networks. The ethnic group social networks highlighted in bold are more closely connected (i.e., considered more insular, internally connected) than the other social networks in each town, where a score above one (1) indicates greater within ethnic group connections than across the whole town's social network.

\begin{tabular}{lccccccc}
\hline \hline & \multicolumn{3}{c}{ Smith } & & \multicolumn{3}{c}{ Jones } \\
\cline { 2 - 3 } \cline { 6 - 7 } & $\begin{array}{c}\text { Anglo- } \\
\text { Celtic }\end{array}$ & Italian & Other & & $\begin{array}{c}\text { Anglo- } \\
\text { Celtic }\end{array}$ & Italian & Other \\
\hline Anglo & $\mathbf{1 . 0 3}$ & & & & 0.93 & & \\
Italian & 0.73 & $\mathbf{1 . 3 2}$ & & & $\mathbf{1 . 2 7}$ & $\mathbf{1 . 5 4}$ & \\
Other & $\mathbf{1 . 1 0}$ & 0.00 & $\mathbf{3 . 4 8}$ & & 0.81 & 0.00 & 0.00 \\
\hline
\end{tabular}

Results show that both community social networks exhibit some modularity. Smith was fairly modular (Anglo-Celtic, Italian, and Other groups generally clustering within each ethnic group but not between), but Jones was more centralized - the Italian group seemed fairly densely connected and the Anglo-Celtic group linked this core to "other" entities. However, Jones showed that there were greater links between its modules, while Smith had more ethnic enclaves operating.

\section{Functions}

Four SES functions were investigated for each community: an individual's identification with community, personal happiness (or personal satisfaction), an individual's perception of community resilience/adaptive maintenance, and the capacity of the community to envisage alternative future scenarios (different from status quo).

An individual's identification with their community was similar in both towns (Table 3). However, Smith had higher personal happiness/satisfaction than did Jones (Table 3). We attribute this to Smith being a larger, less isolated town with more facilities and especially better medical, hospital, and social worker support and educational facilities, whereas Jones' very isolation and lack of facilities engendered identity and pride equal to that of Smith. In both towns, the mainstream ethnic group (Anglo-Celtic) had a greater sense of community identity and was happier $(p=0.05)$ than the "Other" ethnic group, who considered themselves marginalized (Table 3). All ethnic groups consistently scored community resilience higher in Smith than in Jones, although the differences were not statistically significant (Table 3).

A focus group in each community, facilitated by the research team, sought to explore whether these communities could envisage alternative future identities, and if so, did the community think it should continue to adapt to current drivers 
Table 3. Scores of an individual's positive identification with the community, happiness (or satisfaction), and perception of community resilience from survey.

\begin{tabular}{|c|c|c|c|c|c|c|c|}
\hline & \multirow[b]{2}{*}{ Ethnic group } & \multicolumn{3}{|c|}{ Smith } & \multicolumn{3}{|c|}{ Jones } \\
\hline & & Anglo-Celtic & Italian & Other & Anglo-Celtic & Italian & Other \\
\hline \multirow[t]{2}{*}{ Positive identification with community } & Score & 4.251 & 4.000 & 3.667 & 4.341 & 4.667 & 4.056 \\
\hline & Std error & 0.072 & 0.226 & 0.256 & 0.106 & 0.196 & 0.277 \\
\hline \multirow[t]{2}{*}{ Happiness (satisfaction) } & Score & 3.423 & 3.222 & 3.067 & 3.073 & 2.972 & 2.000 \\
\hline & Std error & 0.051 & 0.161 & 0.216 & 0.075 & 0.139 & 0.482 \\
\hline \multirow[t]{2}{*}{ Community resilience/adaptive maintenance } & Score & 4.208 & 4.111 & 3.600 & 3.902 & 3.833 & 3.500 \\
\hline & Std error & 0.070 & 0.219 & 0.294 & 0.103 & 0.190 & 0.657 \\
\hline
\end{tabular}

of change (i.e., adaptive maintenance) or transform to new identities. The focus group drawn from Smith showed an inability to envision futures other than variations on, or embellishments to, its current trajectory. By contrast, Jones (which contained individuals from each ethnic group) quickly envisioned and supported new trajectories and alternative futures. The new trajectories identified by the focus groups for Smith and Jones are summarized in Table 4.

The results indicate that Smith exhibited functions of strong personal satisfaction with status quo and positive identification with the community, and it perceived itself as having high community resilience or adaptive maintenance. Jones had strong personal identification with the town but was less satisfied with the status quo and had a lower ranking of community resilience. However, unlike respondents in Smith, respondents in Jones could envisage alternative futures which necessitate transformative change, not adaptive maintenance. Using these emergent functions as metrics for future community change, we see that Smith will undergo adaptive maintenance, while Jones is more likely to embark on transformative change into the future.

\section{DISCUSSION}

This preliminary or proof-of-concept research has demonstrated that it is practicable to measure a range of metrics encompassing built, natural, human, and social capitals and social networks to holistically assess SES identity, feedbacks, structure, and functions. Selected metrics (once further tested) can be used by policy-makers and communities to purposively strengthen or change SES characteristics and hence design pathways that deliberately achieve positive alternative futures.

Both SES communities are undergoing change. Is it adaptive maintenance or a transformation? Our interrogation of identity, feedbacks, structure, and functions through the use of a select set of metrics is to trial an assessment (or predict) if an SES system will maintain itself and/or transform for a sustainable future.

The results indicate that while the towns are currently similar in identity and the drivers for change, the resulting futures are expected to be different (Table 4). Smith, we predict, will continue to undergo adaptive maintenance, using existing social networks, self-identification with status-quo, happiness with community, and inward focused current social feedbacks, structures, and functions. By contrast, Jones, through the use of its more open networks (potentially an example of panarchy), latent capitals, and lack of satisfaction with community status-quo, could effect a transformation, seeking a new identity, structure, and functions.

Pearson and Pearson (2012) posit that adaptive maintenance is a self-reinforcing status of an SES, resulting in the maintenance of system-identity, feedbacks, structures, and functions-whereas transformation occurs when these characteristics substantially change. We explore this separation of system change more fully by identifying how a community undergoing adaptive maintenance (Smith) exhibits positive self-identification with SES, happiness (which could be interpreted as satisfaction with the statusquo), and closed and well internally linked social networks with natural, built, human, and social capital stocks appropriate for its current identity. Consistent with the argument, more mainstream, contented ethic group(s)specifically, the Anglo-Celtic and Italian groups-had statistically higher scores for resilience than the marginalized "Other" ethnic group (Table 3). Further, leading us to postulate that Smith with its self reinforcing of current SES characteristics is undergoing resilient or adaptive maintenance change.

Alternatively, Jones is seemingly able to effect positive transformational change as exhibited by dissatisfaction with status-quo, strong community identity, open networks, and an ability to foresee and lead to alternative futures that are not aligned to current practices - that is, changing the SES to have different identity, feedbacks, structure, and functions.

What metrics, then, will contribute to a positive, purposeful transformation? Table 5 proposes a list of metrics within each SES characteristic that could be considered necessary for transformation or adaptive maintenance, or are shared between the two. 
Table 4. Future scenarios, developed by consensus in workshops.

\begin{tabular}{|c|c|c|c|}
\hline Smith's: future & $\begin{array}{l}\text { Glities } \\
\text { Hubal Water Innovation and Ecotourism } \\
\text { Hub }\end{array}$ & Integrated Water Future & Worse than Dry \\
\hline Summary & $\begin{array}{l}\text { The community integrates its agricultural, } \\
\text { industrial, and environmental sectors to } \\
\text { become a world leader in the use, } \\
\text { manufacture, management, export, } \\
\text { RandD, and consultation services for } \\
\text { "smart" water systems. Smith is } \\
\text { transformed into a community whose } \\
\text { culture and practices reflect a deeply } \\
\text { integrated use of water. }\end{array}$ & $\begin{array}{l}\text { The community prepares for greater water } \\
\text { scarcity by increasing farming efficiency, } \\
\text { investing in RandD to maintain its } \\
\text { agricultural and horticultural industries, and } \\
\text { expands value-added food processing and } \\
\text { manufacturing. The community also begins } \\
\text { to cope with its aging population by } \\
\text { expanding its aged-care sector. }\end{array}$ & $\begin{array}{l}\text { The community experiences a rapid, } \\
\text { disruptive change in the availability of } \\
\text { water, which leads to collapse of rice } \\
\text { production, declining economy and } \\
\text { population, closure of local businesses, and } \\
\text { farm consolidation. The need for } \\
\text { nonfarming sources of income increases the } \\
\text { importance of ecotourism. }\end{array}$ \\
\hline $\begin{array}{l}\text { Type of change } \\
\text { required }\end{array}$ & Adaptive maintenance & Adaptive maintenance & Adaptive maintenance \\
\hline \multicolumn{4}{|c|}{ Jones': future identities } \\
\hline & Business as usual & $\begin{array}{l}\text { Horticultural Innovation and Renewable } \\
\text { Energy Hub }\end{array}$ & Diversity and Cultural/Eco-Tourism Hub \\
\hline Summary & $\begin{array}{l}\text { Jones' farmers seek to maintain } \\
\text { productivity and output in the context of } \\
\text { increasing water scarcity by increasing } \\
\text { the size of farms and making more } \\
\text { extensive use of "smart" irrigation } \\
\text { systems. The modest expansion of full- } \\
\text { time work opportunities associated with } \\
\text { bigger farms and the attendant demand for } \\
\text { housing helps maintain the community's } \\
\text { stocks of all capitals. }\end{array}$ & $\begin{array}{l}\text { The need to maintain productivity in the } \\
\text { context of water scarcity, reduce carbon } \\
\text { emissions, and decrease dependence on } \\
\text { fossil fuels leads to the expanded use of } \\
\text { irrigation technologies, and the creation of } \\
\text { a Table Grape Research Center and solar } \\
\text { energy infrastructure. This increases the } \\
\text { demand for more skilled workers and } \\
\text { infrastructure, which increases all capitals. }\end{array}$ & $\begin{array}{l}\text { The combination of a long history of multi- } \\
\text { culturalism, strong leadership, and need for } \\
\text { nonfarm sources of income leads to the } \\
\text { creation of an Aboriginal Cultural Center, a } \\
\text { Diversity Center, and an asylum-seeker } \\
\text { processing center that helps successful } \\
\text { asylum seekers integrate into society. This } \\
\text { increases the demand for skilled workers } \\
\text { and infrastructure, which increases all } \\
\text { capitals. }\end{array}$ \\
\hline $\begin{array}{l}\text { Type of change } \\
\text { required }\end{array}$ & Adaptive maintenance & Adaptive maintenance and transformation & Transformation \\
\hline
\end{tabular}

Most importantly, positive transformation requires a capacity to identify alternative futures and for those individuals to be sufficiently articulate that these futures are plausible (Table 5). If happiness with an existing community is a benefit that will contribute to resilience, unhappiness is an attribute that may drive transformation. In the present study, high levels of unhappiness will result in change either through people leaving, becoming uncooperative or rioting (as has happened in Jones), or contributing positively to transformation to a perceptually different community having different (or perhaps additional, multiple) goals.

We suggest vision and unhappiness are necessary, but not sufficient, preconditions because they may equally cause negative transformation. Positivity requires a highly positive identification with the community (to avoid leaving or "doing harm"), and high preparedness to contribute to building social networks and capital, but not (we suggest) necessarily high existing social networks and capital that is engaged in maintaining the existing SES. Aligned with, but different from, preparedness to contribute, is the need for individual pro-activity and leadership. Jones showed all these characteristics, interestingly most strikingly among the marginalized "Other" ethnic group.

Transformability may also be most likely where there are latent capitals, particularly latent social capital, that are not currently engaged in community well-being but are available to be entrained to create a different community with new goals. Latent capitals, however, need to be flexible. For example, the relatively unskilled itinerate labor in Jones is potentially available to work for different purposes and/or take skills training for higher level employment, whereas the unused irrigation infrastructure in Smith is latent capital but sunk, committed to a failing SES that cannot be recreated.

This work has thus demonstrated that metrics can be applied in theory and practice to characterize capacity for adaptive maintenance and transformation of an SES. However, taking heed of Cote and Nightingale's (2011) caution that descriptive resilience work needs further testing before becoming "prescriptive", we advocate that this exploratory research is only a launching pad for further work. Key research questions 
Table 5. Selection of social-ecological system attributes by their capacity for either resilience (adaptive maintenance) or transformation, grouped by system characteristics: identity, feedbacks, structure, and functions. The attributes in bold are the four identified in Walker et al.'s (2006) "Proposition 14: Determinates of Transformation".

\begin{tabular}{|c|c|c|c|c|}
\hline Type of change & Identity & Feedbacks & Structure & Functions \\
\hline $\begin{array}{l}\text { Adaptive maintenance, } \\
\text { including transitions within } \\
\text { existing (irrigated } \\
\text { agriculture and farm- } \\
\text { service) system }\end{array}$ & $\begin{array}{l}\text { Same as current status quo } \\
\text { Unified voice }\end{array}$ & $\begin{array}{l}\text { Closed-networks strongly } \\
\text { linked to internal nodes }\end{array}$ & $\begin{array}{l}\text { Rigidity in institution ideas } \\
\text { and structure } \\
\text { Internal strength and } \\
\text { redundancy within networks }\end{array}$ & $\begin{array}{l}\text { Self-identity or confidence } \\
\text { Happiness: satisfaction with } \\
\text { status-quo }\end{array}$ \\
\hline $\begin{array}{l}\text { Attributes common to both } \\
\text { trajectories }\end{array}$ & & $\begin{array}{l}\text { Fragile to a crisis, which } \\
\text { stimulates change }\end{array}$ & $\begin{array}{l}\text { Modularity (nested } \\
\text { networks) } \\
\text { Amount of capitals }\end{array}$ & $\begin{array}{l}\text { Positive identification with } \\
\text { existing community } \\
\text { Leadership: personal pro- } \\
\text { activity } \\
\text { Trust }\end{array}$ \\
\hline $\begin{array}{l}\text { Transformation: capacity } \\
\text { to envisage and support } \\
\text { different purposeful system } \\
\text { (s) }\end{array}$ & $\begin{array}{l}\text { Incentive to change } \\
\text { Different from status quo by } \\
\text { scale, focus, and direction } \\
\text { Dissenting voices }\end{array}$ & $\begin{array}{l}\text { Open-networks linked to } \\
\text { external nodes, (cross-scale } \\
\text { awareness) }\end{array}$ & $\begin{array}{l}\text { Groups driving change } \\
\text { (internal or external) } \\
\text { Latent capitals } \\
\text { Flexibility in institutions }\end{array}$ & $\begin{array}{l}\text { Capacity to identify new } \\
\text { vision/goal } \\
\text { High innovation } \\
\text { Dissatisfaction with status-quo } \\
\text { Individual responsibility } \\
\text { Institutional desire to change }\end{array}$ \\
\hline
\end{tabular}

that have arisen include refinement of the four characteristics and determination of how they differ for adaptive maintenance or/and transformation. This requires further empirical testing of the four characteristics in urban and non-Australian settings to determine their empirical worth and robustness. Attention also needs to be given to issues of power, cross-scale interactions, and closer interactions with environmental systems as identified in Pelling (2011).

Additionally, the work has raised two key policy questions: How can public policy measure a town's progress along a transformation path, untangling when does a transformation town turn into an adaptive maintenance phase?

\section{CONCLUSION}

Our research supports the proposition that adaptive maintenance or resilience is different from transformation. It suggests four differentiating characteristics that may separate them, and possible metrics to measure these differences. Some metrics contributed to both types of system change. While our research has been largely exploratory within the hypothesis that SES resilience and transformation depend on separate but overlapping characteristics, categorization within the matrix in Table 5 provides a basis for refinement.

Responses to this article can be read online at: http://www.ecologyandsociety.org/issues/responses. php/5100

\section{Acknowledgments:}

The authors are indebted to the Melbourne Sustainable Society Institute for funding this research. Additionally, this work was not possible without the countless hours provided by hundreds of people in our two communities-thank you. This manuscript has been significantly improved by the insightful comments of two anonymous referees.

\section{LITERATURE CITED}

Abel, N., D. H. M. Cumming, and J. M. Anderies. 2006. Collapse and reorganization in social-ecological systems: questions, some ideas, and policy implications. Ecology and Society 11(1):17. [online] URL: http://www.ecologyandsociety. org/vol11/iss1/art17/

Anderies, J. M., P. Ryan, and B. H. Walker. 2006. Loss of resilience, crisis, and institutional change: lessons from an intensive agricultural system in southeastern Australia. Ecosystems 9:865-878. http://dx.doi.org/10.1007/s10021-006-0017-1

Australian Bureau of Statistics. 2001. Census of population and housing, CDATA for 1991 and 2001(Cat. No 2040.0.30.001).

Australian Bureau of Statistics. 2006a. Census of population and housing, CDATA for 2006. (Cat. No 2064.0).

Australian Bureau of Statistics. 2006b. An introduction to socio-economic indexes for areas (SEIFA)(Cat. No 2039.0).

Baum, S., R. Stimson, K. O'Connor, P. Mullins, and R. Davis. 1999. Community opportunity and vulnerability in Australia's cities and towns: characteristics, patterns and implications. AHURI/University of Queensland Press, Brisbane, Australia.

Berkes, F., J. Colding, and C. Folke. 2003. Navigating socialecological systems: building resilience for complexity and change. Cambridge University Press, Cambridge, UK. 33-52. http://dx.doi.org/10.1017/CBO9780511541957 
Bettencourt, L. M. A., J. Lobo, D. Helbing, C. Kuühnert, and G. B. West. 2007. Growth, innovation, scaling, and the pace of life in cities. Proceedings of the National Academy of Sciences 104(17):7301-7306. http://dx.doi.org/10.1073/ pnas.0610172104

Biggs, R., S. R. Carpenter, and W. A. Brock. 2009. Turning back from the brink: detecting an impending regime shift in time to avert it. Proceedings of the National Academy of Sciences 106:826-831. http://dx.doi.org/10.1073/pnas.0811729106

Brown, P. R., R. Nelson, B. Jacobs, P. Kokic, J. Tracey, M. Ahmed, and P. DeVoil. 2010. Enabling natural resource managers to self-assess their adaptive capacity. Agricultural Systems 103:562-568. http://dx.doi.org/http://dx.doi.org/10.1016/ j.agsy.2010.06.004

Burns, J. 1995. A strategy for the development of the Smith region. Mimeo.

Carpenter S. R., and W. A. Brock. 2006. Rising variance: a leading indicator of ecological transition. Ecology Letters 9:311-318. http://dx.doi.org/10.1111/j.1461-0248.2005.00877. $\underline{x}$

Carpenter S. R., W. A. Brock, J. J. Cole, J. F. Kitchell, and M. L. Pace. 2008. Leading indicators of trophic cascades. Ecology Letters 11:128-138.

Chapin, F. S., G. P. Kofinas, and C. Folke, editors. 2009. Principles of ecosystem stewardship: resilience-based natural resource management in a changing world. Springer, New York, New York, USA.

Clark, W. C., and N. M. Dickson. 2003. Sustainability science: the emerging research program. Proceedings of the National Academy of Sciences 100:8059-8061. http://dx.doi. org/10.1073/pnas.1231333100

Cote, M., and A. J. Nightingale. 2011. Resilience thinking meets social theory: situating change in socio-ecological systems (SES) research. Progress in Human Geography http:// dx.doi.org/10.1177/0309132511425708

de Groot, R. S. 1992. Function of nature: evaluation of nature in environmental planning, management and decision making. Wolters-Noordhoff BV, Groningen, The Netherlands.

Gunderson, L. H., and C. S. Holling, editors. 2002. Panarchy: understanding transformations in human and natural systems. Island Press, Washington, D.C., USA.

Guttal, V., and C. Jayaprakash. 2008. Changing skewness: an early warning signal of regime shifts in ecosystems. Ecology Letters 11:450-460. http://dx.doi.org/http://dx.doi.org/10.1111/ j.1461-0248.2008.01160.x

Hafi, A., S. Thorpe, and A. Foster. 2009. The impact of climate change on the irrigated agricultural industries in the MurrayDarling Basin. ABARE Conference Paper 09.3:17.
Holling, C. 1973. Resilience and stability of ecological systems. Annual Review of Ecology and Systematics 4:1-23. http://dx.doi.org/10.1146/annurev.es.04.110173.000245

Holmes, J. 2006. Impulses towards a multifunctional transition in rural Australia: gaps in the research agenda. Journal of Rural Studies 22:142-160. http://dx.doi.org/10.1016/j.jrurstud.2005.08.006

Janssen, M. A., Ö. Bodin, J. M. Anderies, T. Enquist, H. Ernstson, R. R. J. McAllister, P. Olson, and P. Ryan. 2006. Toward a network perspective of the study of the resilience in social-ecological systems. Ecology and Society 11(1):15. [online] URL: http://www.ecologyandsociety.org/vol11/ iss $1 / \operatorname{art} 15 /$

Kinzig, A. P., P. Ryan, M. Etienne, H. Allison, T. Elmqvist, and B. H. Walker. 2006. Resilience and regime shifts: assessing cascading effects. Ecology and Society 11(1):20. [online] URL: http://www.ecologyandsociety.org/vol11/iss1/ $\underline{\operatorname{art} 20 /}$

Levin, S. A. 1999. Towards a science of ecological management. Conservation Ecology 3(2):6.

Maguire, B., and S. Cartwright. 2008. Assessing a community's capacity to manage change: a resilience approach to social assessment. Australian Government Bureau of Rural Sciences.

McClanahan, T. R., N. V. C. Polunin, and T. J. Done. 2002. Resilience of coral reefs. Pages 112-164 in L. H. Gunderson, and L. Pritchard, Jr., editors. Resilience and behavior of largescale systems. Island Press, Washington, D.C., USA.

Meadows, D. 2008. Thinking in systems: a primer. Chelsea Green, White River.

Nelson, G. C., M. W. Rosegrant, A. Palazzo, I. Gray, C. Ingersoll, R. Robertson, S. Tokgoz, T. Zhu, T. B. Sulser, C. Ringler, S. Msangi, and L. You. 2010. Food security, farming, and climate change to 2050: scenarios, results, policy options. IFPRI Research Report, December, International Food Policy Research Institute, Washington, D.C., USA.

Nelson, D. R., W. N. Adger, and K. Brown. 2007. Adaptation to environmental change: contributions of a resilience framework. Annual Review of Environment and Resources 32:395-419. http://dx.doi.org/10.1146/annurev. energy.32.051807.090348

Nelson, R., M. Howden, and M. Stafford Smith. 2008. Using adaptive governance to rethink the way science supports Australian drought policy. Environmental Science and Policy 11:588-601. http://dx.doi.org/10.1016/j.envsci.2008.06.005

O'Brien, K. 2011. Global environmental change II: from adaptation to deliberate transformation. Progress in Human Geography http://dx.doi.org/http://dx.doi.org/10.1177/0309$\underline{132511425767}$ 
Olsson P., L. H. Gunderson, S. R. Carpenter, P. Ryan, L. Lebel, C. Folke, and C. S. Holling. 2006. Shooting the rapids: navigating transitions to adaptive governance of socialecological systems. Ecology and Society 11(1):18. [online] URL: http://www.ecologyandsociety.org/vol11/iss1/art18/

Onyx, J., and P. Bullen. 2000. Measuring social capital in five communities. Journal of Applied Behavioral Science 36 (1):23-42. http://dx.doi.org/10.1177/0021886300361002

Parris, T. M., and R. W. Kates. 2003. Characterizing a sustainability transition: goals, targets, trends, and driving forces. Proceedings of the National Academy of Sciences 100 (14):8068-8073. http://dx.doi.org/http://dx.doi.org/10.1073/ pnas. 1231336100

Pearson, C. J., and J. Nasby. 2008. The cultivated landscape. McGill-Queens University Press, Montreal, Quebec, Canada.

Pearson, L. J., and C. J. Pearson. 2012. Societal collapse or transformation, and resilience. Proceedings of the National Academy of Sciences 109(30):E2030-E2031. http://dx.doi. org/10.1073/pnas.1207552109

Pelling, M. 2011. Adaptation to climate change: from resilience to transformation, Routledge, London, UK.

Pelling, M., C. High, J. Dearing, and D. Smith. 2008. Shadow spaces for social learning: a relational understanding of adaptive capacity to climate change within organisations. Environment and Planning A 40(4):867-884. http://dx.doi. org/http://dx.doi.org/10.1068/a39148

Pelling, M., and D. Manuel-Navarrete. 2011. From resilience to transformation: the adaptive cycle in two Mexican urban centers. Ecology and Society 16(2):11. [online] URL: http:// www.ecologyandsociety.org/vol16/iss2/art11/

Rounsevell, M. D. A. T. P. Dawson, and P. A. Harrisson. 2010. A conceptual framework to assess the effects of environmental change on ecosystem services. Biodiversity and Conservation 19(10):2823-2842.

Scheffer, M., F. Westley, W. A. Brock, and M. Holmgren. 2002. Dynamic interaction of societies and ecosystemslinking theories from ecology, economy and sociology. In L. H. Gunderson, and C. S. Holling, editors. Panarchy: understanding transformations in human and natural systems. Island, London, UK.

Schlüter, M., and E. Herrfahrdt-Pähle. 2011. Exploring resilience and transformability of a river basin in the face of socioeconomic and ecological crisis: an example from the Amudarya river basin, Central Asia. Ecology and Society 16 (1):32. [online] URL: http://www.ecologyandsociety.org/ vol16/iss $1 /$ art32/

Smith Shire Council. 2008. Economic Development Strategy 2008. Mimeo.
Tompkins, E., and W. N. Adger. 2004. Does adaptive management of natural resources enhance resilience to climate change? Ecology and Society 9(2). [online] URL: http://www. ecologyandsociety.org/vol9/iss2/art10/

Tschakert, P., and K. A. Dietrich. 2010. Anticipatory learning for climate change adaption and resilience. Ecology and Society 15(2):11. [online] URL: http://www.ecologyandsociety. org/vol15/iss2/art11/

Victorian Government. 2006. Regional matters, an atlas of regional Victoria 2005.

Vogel, C., S. C. Moser, R. E. Kasperson, and G. D. Dabelko. 2007. Linking vulnerability, adaptation, and resilience science to practice: pathways, players, and partnerships. Global Environmental Change 17:349-364. http://dx.doi.org/http:// dx.doi.org/10.1016/j.gloenvcha.2007.05.002

Walker, B., L. Gunderson, A. Kinzig, C. Folke, S. Carpenter, and L. Schultz. 2006. A handful of heuristics and some propositions for understanding resilience in social-ecological systems. Ecology and Society 11(1):13. [online] URL: http:// www.ecologyandsociety.org/vol11/iss1/art13/

Walker, B., C. S. Holling, S. R. Carpenter, and A. Kinzig. 2004. Resilience, adaptability and transformability in socialecological systems. Ecology and Society 9(2):5. [online] URL: http://www.ecologyandsociety.org/vol9/iss2/art5

Walker, B., and R. Lawson. 2006. Case studies in resilience: fifteen social-ecological systems across continents and societies. An appendix to the Ecology and Society Special Feature Exploring Resilience in Social-Ecological Systems. Resilience Alliance. [online] URL: http://www.resalliance. org/1613.php

White, H. C., S. A. Boorman, and R. L. Breiger. 1976. Social structure from multiple networks. I. Blockmodels of roles and positions. American Journal of Sociology 81(4):730-780. http://dx.doi.org/10.1086/226141

Wilson, G. A. 2001. From productivism to post-productivism ... and back again? Exploring the (un)changed natural and mental landscapes of European agriculture. Transaction of the Institute of British Geographers 26:77-102. http://dx.doi. org/10.1111/1475-5661.00007 